\title{
Construction of Pressure Tunnels
}

\author{
Lesław Zabuski \\ Institute of Hydro-Engineering, Polish Academy of Sciences, 7 Kościerska, 80-328 Gdańsk, Poland, \\ e-mail: leslawzabuski@ibwpan.gda.pl
}

(Received November 13, 2019; revised February 26, 2020)

\begin{abstract}
The paper focuses on two pressure tunnels in the design of "Kąty-Myscowa" water reservoir. One of them serves as a discharge conduit, whereas the other plays an energetic role. Their depths range between 0 and 75 metres and their diameters equal $5 \mathrm{~m}$. Tunnels are located in the rock mass of Carpathian flysch which is anisotropic and heterogeneous, composed of layers of sandstone and clay shales and intersected with interbedding fissures and numerous joints. The paper is divided in two parts. The first part focuses on methods of excavating and supporting, as well as injecting and sealing (i.e. waterproofing) the tunnel. In the second part, a numerical analysis using the FLAC2D code based on the finite difference method was carried for calculating displacements and internal forces in the preliminary support and in permanent lining. Results of the analysis allow for the assessment of conditions in the tunnel during its excavation and exploitation stages.
\end{abstract}

Key words: pressure tunnel, Carpathian flysch, numerical analysis, FLAC code

\section{Introduction - Operating Conditions}

The paper describes the principles of executing and operating pressure tunnels, using the water reservoir "Kąty-Myscowa" (southern Poland) as an example. The reservoir was designed at the end of the 20th century but the project has been discontinued in its initial stages. Recently, the idea has been put forward to continue the project, however (e.g. TVP3 Rzeszów 16.10.2016, https://nowyzmigrod24.pl/ 28.01.2019; https://nowiny24.pl/katymyscowata-zaporamusipowstac/ar/6088059). Given this context, the current paper seems fully justified.

Hydrotechnical tunnels are specific underground constructions, which conduct water between reservoirs located at different levels (Zabuski and Thiel 2000a, Zabuski 1983, 1984, Brekke and Ripley 1993). There are two main types of these constructions, namely conventional (i.e. "non-pressure") and "pressure" tunnels. In the former, water flows freely through a pipe without exerting any pressure on its walls, as

(C) 2019 Institute of Hydro-Engineering of the Polish Academy of Sciences. This is an open access article licensed under the Creative Commons Attribution-NonCommercial-NoDerivs License (http://creativecommons.org/licenses/by-nc-nd/3.0/). 
there is no difference between the levels of elevation of reservoirs or the difference is very small. In the latter, the difference between these levels causes pressure on the tunnel walls. The main distinction between the conventional and pressure tunnels is that, unlike the former, the latter have the ability to withstand internal pressure (Benson 1989, Thiel and Zabuski 1977, Seeber 1975, 1999, Friedrich and Zabuski 1987).

The only underground pressure tunnels in Poland are those in Porąbka-Żar. There were also plans to construct this type of tunnels in Młoty (Thiel and Zabuski 1977) but, in the end, they were not carried out. Pressure tunnels were the author's area of interest in the 1980s, when he published a few papers drawing on foreign, mainly Austrian, literature (Zabuski 1983, 1984, Friedrich and Zabuski 1987).

This paper focuses on two pressure tunnels in the design of "Kąty-Myscowa" water reservoir (Fig. 1). One of them serves as a discharge conduit, whereas the other one additionally plays an energetic role. Their depths range between 0 and 75 meters and the diameters equal $5 \mathrm{~m}$. The altitude difference of the reservoir ("upper water") and the outlet ("lower water") is approximately $50 \mathrm{~m}$. This means that the water pressure in the lowest point is approximately equal to $500 \mathrm{kPa}$. The water flow is irregular, as the water inflow is alternately opened and closed. This "pulsation" causes additional dynamic pressure, which constitutes about $30 \%$ of the static value (i.e. $500 \mathrm{kPa}$ ). This means that the total pressure, the sum of these two components, equals 650 about $\mathrm{kPa}$. For safety reasons, the value $p_{w}=800 \mathrm{kPa}$ is assumed in the further analysis. Since this pressure is relatively low, the tunnels could be considered "low-pressure" constructions.

The paper is divided in two parts. The first one focuses on the methods of excavating and supporting, as well as injecting and sealing (i.e. waterproofing) a tunnel. The second one discusses geomechanical and numerical models for calculating displacement and internal forces in the preliminary support and in permanent lining. Additionally, analyses of these characteristics and results obtained, both at the excavation and exploitation stages, are presented (Zabuski 2000).

\section{Part I. General Characteristics of Pressure Tunnels}

\section{The Method of the Tunnel Excavation and Supporting}

The designed tunnels will be excavated in the rock mass of Carpathian flysch, consisting mainly of the "Cergowskie" layers. The rock mass is anisotropic and heterogeneous, and composed of sandstone layers inter-layered with clay or marly shales. Marls and hornstones are also present. The rock mass is intersected with inter-bedding fissures and numerous joints are present as well (Zabuski 1997a-c, 1998, 2002, 2019). The joints are arranged in joint sets, which are approximately perpendicular to the layering. According to the geomechanical RMR classification (Bieniawski 1984), Q 


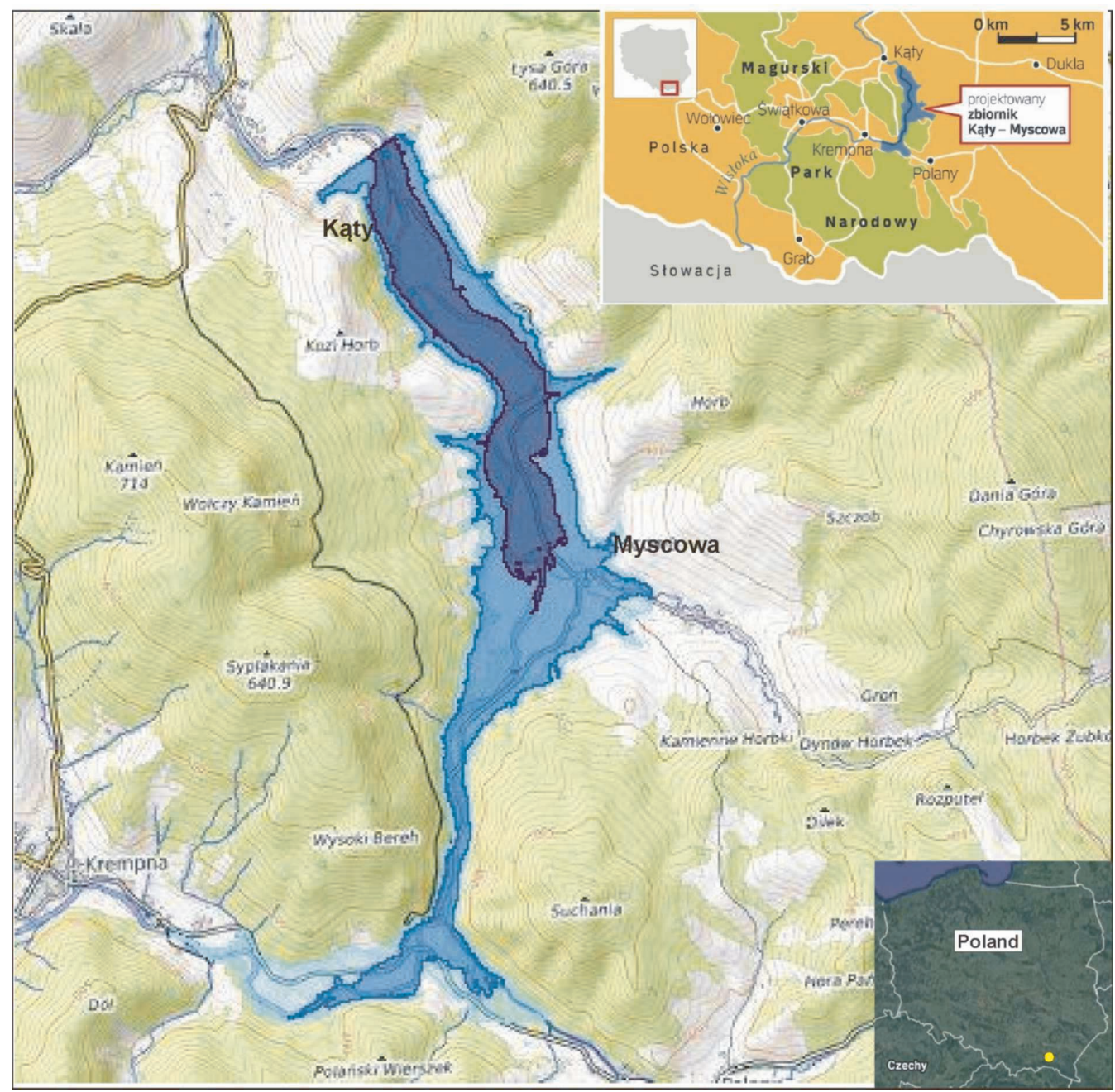

Fig. 1. Map of "Kąty-Myscowa" water reservoir

(Barton et al 1974), RSR (Costa-Pereira and Rodrigues-Carvalho 1987), Terzaghi, RMR, MR, Lauffer (Müller 1978, Singh and Goel 1999) and Polish classifications KF and KFG (Bestyński et al 1989), the rock mass mainly belongs to the IVth and Vth classes, only occasionally falling into the IIIrd class. Due to high heterogeneity, it is impossible to determine the contents of the mass belonging to each class along the tunnels. It is therefore usually assumed that the rock mass falls into the class IV along its whole length. Accordingly, the excavation technique and the type of support applied correspond with the geomechanical conditions of the IVth class.

There are two main stages of tunnel constructing. In the first one, it is excavated using a conventional method (i.e. extraction of the rock by explosives) and supported with the use of preliminary support. This support withstands all external loadings 
resulting from the stress exerted by the rock mass (Olsson et al 1997). Stability of the tunnel is thus provided. In the second stage, permanent lining is installed in an already stable excavation. Its role is to improve stability of the tunnel by withstanding deformations occurring over time. The permanent lining withstands the loadings, which develop as a result of ageing of the elements of preliminary support (e.g. corrosion of the rockbolts). Moreover, it facilitates the flow of water and plays an aesthetic role.

The most vital technical problems usually emerge at the first stage of excavation. In order to perform the excavation in a safe manner, the following principles should be folowed:

- The tunnel should be excavated and supported within the shortest possible period of time.

- It is necessary to use an active support, which adheres tightly to the excavation walls and deforms together with the rock.

- Rockbolting is an appropriate and functional element of support: it strengthens the rock mass surrounding the excavation, decreasing its deformations (although it is not a typical "supporting" element (Huang et al 2002).

- Prompt and flexible reactions to the issues arising during excavation (regardless of hard-coded rules of the contract); monitoring displacement and adjustment of the excavation and supporting methods to the measured values.

In difficult and complex geological conditions, the above requirements are met by support consisting of rockbolts, shotcrete and steel arches. Taking into account the guidelines put forward by other authors on the basis of different classifications (e.g. Bieniawski 1984) and drawing upon his own experiences, the author recommended the support consisting of:

$-3.0 \mathrm{~m}$ long steel bolts, $22 \mathrm{~mm}$ in diameter, cemented in the boreholes, spaced $1 \times 1 \mathrm{~m}$;

- $20 \mathrm{~cm}$ thick shotcrete layer, reinforced by a $10 \times 10 \mathrm{~cm}$ steel mesh made of a wire $6 \mathrm{~mm}$ in diameter; and

- steel arches (V-25) with parameters meeting the producer's specifications, spaced $1 \mathrm{~m}$ along the tunnel axis.

If the rock mass falls into the IVth class, the tunnel can be excavated in one step. When (exceptionally) the rock mass is of a worse quality, it is a good practice to excavate a "kalota" (a 1.8-2.0 m high roof part of the tunnel) approximately 3-4 m ahead of the full cross-section is excavated. It is, however, necessary to close the circular shape of the tunnel as fast as possible.

The final lining is installed when the displacements of the tunnel walls become very small or do not occur anymore. Because of the unique nature of a pressure tunnel, deformation of a rock mass and resulting external loadings could be beneficial, however. This is because the stresses of compression generated in the lining partially compensate for the tension caused when filling the tunnel with water. Nevertheless, 
this effect is only advantageous when deformations are relatively homogeneous on the whole perimeter of the tunnel. Otherwise, their significant heterogeneity could cause an increase in the bending moments in lining.

As can be seen from the foregoing, it is necessary to systematically monitor displacements during the excavation work, as this allows for making correct decisions as for the modes of excavation and support.

\section{Sealing and Injection}

\subsection{Sealing (Waterproofing)}

A hydrotechnical pressure tunnel must be absolutely waterproof. It means that the inflow or outflow of water should be prevented at all costs. This issue has been recognised since the first pressure tunnels were built (Wannenmacher et al 2013).

There are different waterproofing solutions available. Arguably the best, and practically a flawless method involves the utilisation of a steel shell (Pachoud and Schleiss 2016, Thiel and Zabuski 1977). In addition to having waterproofing qualities, the shell is able to withstand internal water pressure generated in the tunnel. The disadvantage of this method, however, is its low ability to withstand external stresses, which, in some cases, can lead to the buckling phenomenon. It is therefore essential to apply a layer of concrete between the shell and rock mass. Yet another issue is a high cost of the shell. For these reasons, the use of this kind of lining is usually restricted to high-pressure tunnels, where the pressure reaches several thousands of $\mathrm{kPa}$ or more.

Another commonly used waterproofing method is an application of reinforced concrete lining (Kumar and Singh 1990, Zabuski 1983). Even though a concrete shell withstands external forces effectively, it is not waterproof: due to the internal pressure exerted by water in the tunnel, cracks develop in concrete, forming channels that conduct the water. Nevertheless, there are some methods of overcoming this disadvantage: while applying a tight foil seems to be the most cost effective solution, the least economic one is the application of a very thick lining.

Experts outside of Poland have long faced a challenging choice between steel and concrete shells. On one hand, steel ensures an ideal waterproofing but, on the other, its cost is high. Although the cost of concrete is much lower, its tightness is not satisfactory, especially when internal pressures are of moderate values. Using a combination of concrete and PVC foil seems a reasonable solution. Seeber (1999) writes: (...)due to the difference between the cost of expensive steel shell and relatively cheap concrete lining in the past the concrete lining was applied in the constructions in which steel shell should be introduced. It was the reason of the accidents. The combination of the concrete shell and PVC foil provides the lining both resistant and leak tight. Accordingly, foil has been increasingly used in both pressure and conventional tunnels.

Special technologies should be applied in pressure tunnels. This is because:

- the foil is not able to withstand internal and external pressures and should be therefore combined with concrete shell to produce lining; and 


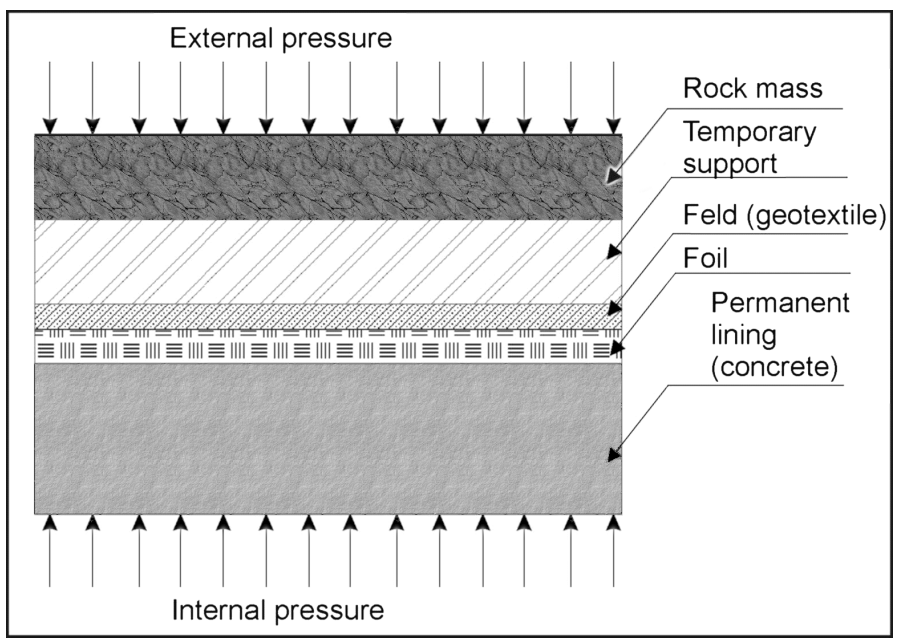

Fig. 2. Waterproof casing of the hydrotechnical pressure tunnel

- the tunnel lining should be a well-matched construction, i.e. no gaps between concrete shell, foil and rock mass are allowed; the elements of the system should act together.

In line with the above requirements, the lining system is composed of the following layers (see Fig. 2):

- preliminary support (e.g. shotcrete layer),

- felt of geotextile layer,

- PVC (polyvinyl chloride) or polypropylene foil $23 \mathrm{~mm}$ thick, and

- reinforced concrete lining.

In the first realizations of tunnels, foil was laid directly on the rough shotcrete wall, which caused it to break. Over time, this issue has been solved by putting felt or geotextile layer between the foil and shotcrete 3 .

The PVC foil is not subject to solar radiation and big fluctuations of the temperature so its ageing process is very slow. Polyethylene foils are less prone to ageing and provide higher security than PVC foils (although their cost is higher). It should be noted that foil must be sufficiently extensible as it is subject to tension and elongation exerted by the internal pressure acting in the tunnel4.

\subsection{Injection into the Gap behind the Lining}

An injection behind the lining is a widely performed operation when constructing a pressure tunnel (Wannenmacher et al 2015). It serves two main purposes:

- eliminating gaps between the rock mass and tunnel support, and connecting the lining and foil tightly;

- preliminary compressing (pre-stressing) of the construction. 


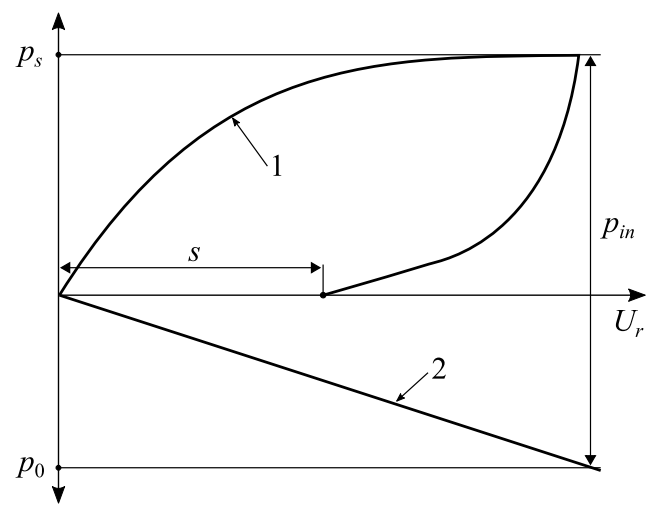

Fig. 3. Scheme of the joint-work of the tunnel lining with the surrounding rock mass

Concrete lining should be always pre-stressed, even if the duration of its effects is not crucial. The aim of injection in this case is to bond all layers into one "system". The elements of this system should be and remain tightly bonded together when the tunnel is filled with water exerting internal pressure, and when emptying it. Figure 3 illustrates this process. The first filling of the tunnel leads to radial outwards displacement Ur of the lining and the rock mass. The rock mass deforms according to the line 1 , while the deformation of the lining follows the line 2 . The pressure is jointly withstood by the lining and the rock mass $\left(p_{i n}=p_{s}+p_{o}\right)$.

Emptying the tunnel causes deformations of the rock mass and lining; while elastic lining returns to its original shape, residual deformations are irreversible and remain in the rock mass. As a consequence, a gap (of width " $s$ ") is created between the lining and the rock mass. The purpose of injection in this case is to fill this gap so as to ensure joint-work of the lining and rock mass in subsequent filling/emptying cycles.

An injection in a pressure tunnel differs significantly from an injecton in a "conventional" tunnel. While the latter serves to seal and strengthen the rock mass, the aim of the former is to introduce an inject into the gaps separating the rock and support, and the support and lining, and to fill this gap (Wannenmacher et al 2015). The method suggested for application in Kąty-Myscowa is described below.

Figure 4 presents the principles of the method elaborated by TIWAG (Tiroler Wasserkraftwerke $A G$ ), which recommends that injection plastic tubes perforated in $1 \mathrm{~m}$ spacing are placed on the walls of the excavation before the foil and lining are installed. Next, the inject mixture is pushed into these tubes through holes (4). Rubber sleeves (6) are put on the tubes to cover the holes in order to prevent the return outflow of the inject. This operation should be performed in the first cycle of filling the tunnel with water. The mixture is pushed behind the foil through injection conduits (3) to fill the gap until assumed pressure is reached. The connection between the internal space of the tunnel and the space behind the foil should be constructed in the way that helps prevent a leakage of the inject into the tunnel. This solution is illustrated in Figure 5. As can be seen, two options are possible, i.e. conducting pipe or a plastic tube. 


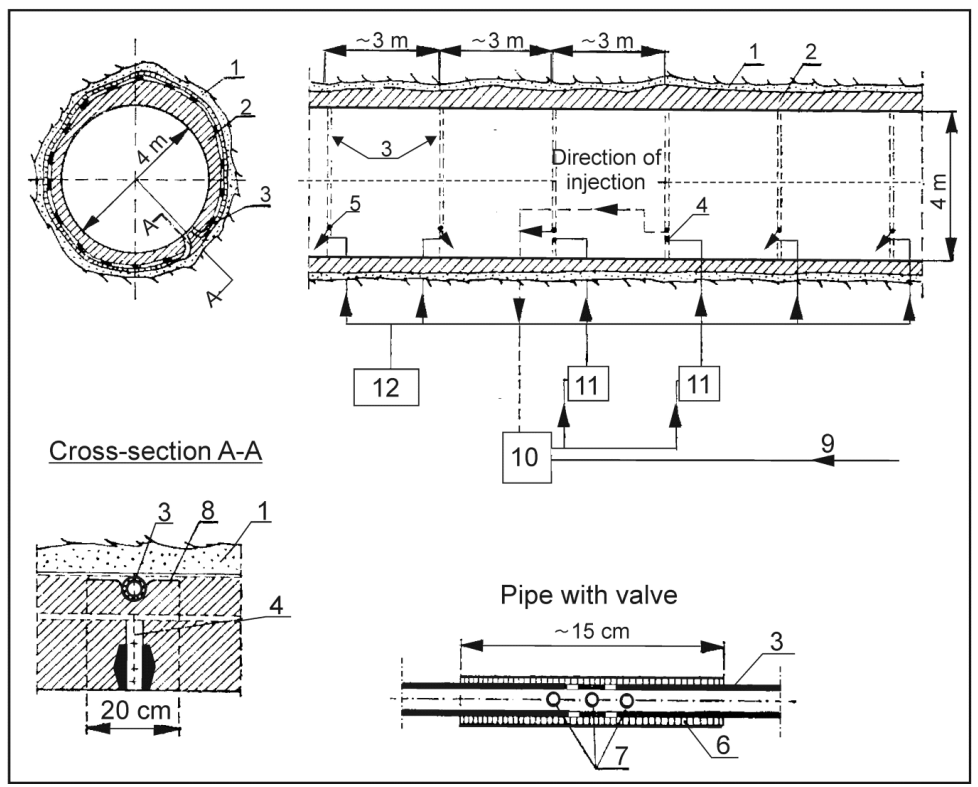

Fig. 4. System of the injection to separating gap (Seeber 1975); 1 - preliminary support (shotcrete), 2 - final lining (concrete), 3 - injection conduit, 4 - injection hole, 5 - plughole, 6 - rubber sleeve, 7 - perforation of the injection hole, 8 - PVC plate, 9 - system conducting the mixture, 10 - dasher, 11 - injection pump, 12 - water pump

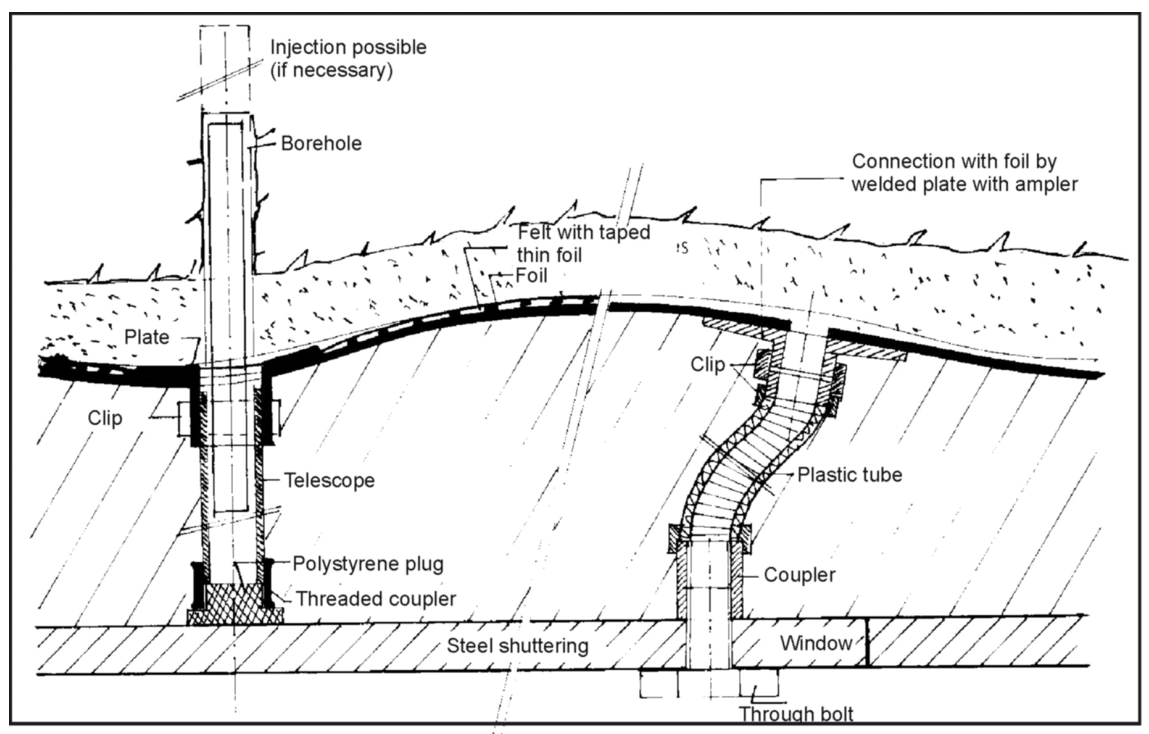

Fig. 5. Pre-stressed concrete lining with the plastic foil. Injection couplings: conducting pipe or plastic tube (Seeber 1999) 
The parameters of injection and its properties such as contents and density of the mixture, its pressure, and the arrangement of conduits should be selected on the empirical basis. In case of shallow excavations, the limit of pressure is closely related to the magnitude of the lateral horizontal stress $\sigma_{x}$ in the rock mass and should not be larger than this stress. Although the value of $\sigma_{x}$ in the case analysed here remains unknown, its estimation is possible, assuming that it ranges between $30-50 \%$ of the vertical pressure $p(p=\gamma H$, where $\gamma$ represents the unit weight of rock mass and $H$ is the depth). If the tunnel is very shallow, it is still possible to fill the gap, but its pre-stressing is barely possible or at least problematic due to a low level of the $\sigma_{x}$ stress component.

It is planned to apply an injection in the tunnels in Kąty-Myscowa. Its long-term effect is not taken into account, since the depth of the tunnels is small, which means that the pressure can decrease or disappear relatively fast, increasing stresses in the concrete shell and causing cracks. Thus, applying a foil is crucial.

\section{Part II. Calculations of Internal Forces and Displacements in the Tunnel Support and Lining}

The first part of the paper deals with the methods of excavating and supporting a tunnel, and the issues relating to waterproofing and injection behind the lining are addressed. This second part of the paper describes the calculations that are carried out to determine the behaviour of the tunnel and the surrounding rock mass, and, most of all, to evaluate the internal forces and displacement developing in the support and lining.

\section{Program of Calculations}

The stages of calculation correspond to the sequence of the tunnel excavation stages and the regime of its work during exploitation. The sequence of calculations is sketched in Figure 6.

Calculation for the natural state Nat determines the distribution of stress before the execution of excavation. The displacements calculated at this stage are next "zeroed" and the data on stresses are used at the subsequent stages of the calculation.

Calculation stage $\mathbf{O W}$ corresponds to the preliminary supported tunnel. The radius of complete cross-section is $2.5 \mathrm{~m}$. The support is formed with shotcrete layer reinforced by steel arches and a set of rockbolts distributed around the tunnel.

The calculations that could be carried out at the stages following the installation of permanent lining are divided into four variants. This division corresponds to different situations considered here. The variant involving dry rock mass is marked as " 1 ", while the one involving wet mass is marked as "2". The groundwater level is equal to the maximum level of water in the reservoir, i.e. $356 \mathrm{~m}$ a.s.l. The second criterion 


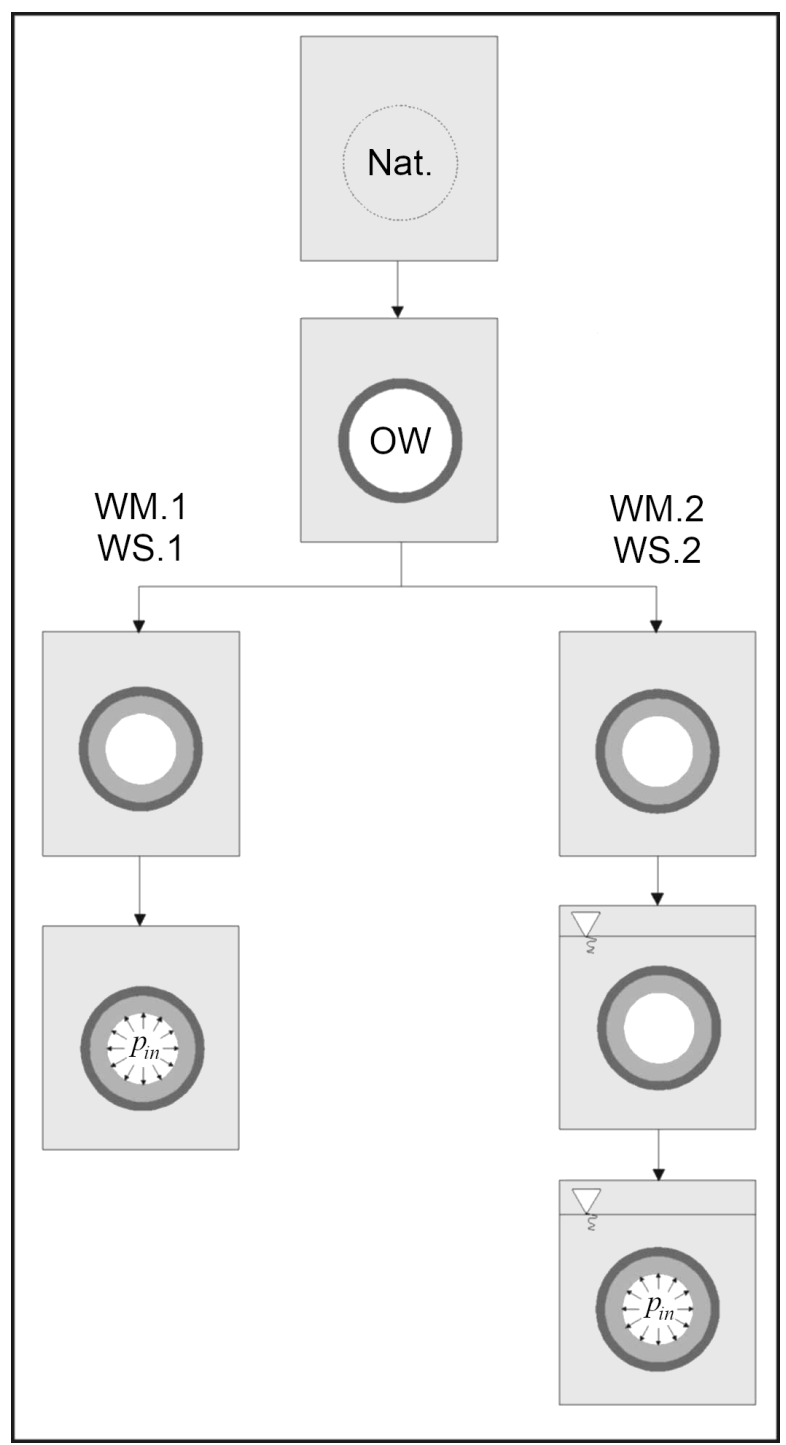

Fig. 6. Calculation stages and variants consistent with the sequence of the tunnel excavation and exploitation

for the division is related to the weakening of the rock mass expected to occur during exploitation of the tunnel. It was modelled based on the decrease in the parameters and the assumption that they equal $90 \%$ of their original values. The variants characterized by the original parameters are marked as WM and those characterized by weaker parameters are marked as WS. Table 1 presents the above-defined variants.

The first stage of each variant is the same, with calculations being performed for the lined tunnel without internal pressure, i.e. for the period between a complete construction and the first filling the tunnel with water. At the second stage of variant 1 (dry 
Table 1. Calculation stages and variants

\begin{tabular}{|l|c|c|c|c|}
\hline \multicolumn{1}{|c|}{$\begin{array}{c}\text { Calculation } \\
\text { stage }\end{array}$} & \multicolumn{4}{c|}{ VARIANT } \\
\cline { 2 - 5 } & WM.1 & WM.2 & WS.1 & WS.2 \\
\hline Natural state & $\times$ & $\times$ & $\times$ & $\times$ \\
\hline Supported tunnel (preliminary support) & $\times$ & $\times$ & $\times$ & $\times$ \\
\hline Tunnel permanently lined, $p_{w}=0$ & $\times$ & $\times$ & $\times$ & $\times$ \\
\hline $\begin{array}{l}\text { Tunnel permanently lined, } p_{w}=0, \\
R W L=\text { Water Level in the Reservoir }\end{array}$ & & $\times$ & & $\times$ \\
\hline $\begin{array}{l}\text { Tunnel permanently lined, } \\
p_{w}=800 \mathrm{kPa}, R W L=0\end{array}$ & $\times$ & & $\times$ & \\
\hline $\begin{array}{l}\text { Tunnel permanently lined, } \\
p_{w}=800 \mathrm{kPa}, R W L=\text { Water Level } \\
\text { in the Reservoir }\end{array}$ & & $\times$ & & $\times$ \\
\hline $\begin{array}{l}\left.\text { Emptying of the tunnel ( } p_{w}=0\right), \\
R W L=\text { Water Level in the Reservoir }\end{array}$ & & & & $\times$ \\
\hline
\end{tabular}

mass), the tunnel is filled (internal pressure $p_{i n}$ ). At the second stage of variant 2 , the pressure pin was applied after filling the reservoir; two stages were therefore analyzed (see the sequence on the right of Figure 6) - the one with water in the rock mass and the following one, with the pressure $p_{i n}$.

In addition to the stages described above, the most unfavorable variant WS. 2 was analyzed after emptying the tunnel (i.e. when $p_{\text {in }}=0$ ). The results help to determine residual deformations, which occur when water flows through the tunnel.

The calculations were carried out for three depths of the tunnel, namely $H=15 \mathrm{~m}$, $45 \mathrm{~m}$ and $75 \mathrm{~m}$. On one hand, it was expected that the forces and deformations in the lining will be most unfavorable in the deepest tunnel. On the other, however, the quality of the rock mass improves as the depth increases.

\section{Calculation Method and Numerical Model}

\subsection{Calculation Method}

Calculations were carried out by using FLAC2D (FLAC 1999) program for plane strain conditions, based on the finite difference method. This program has the following features in terms of its usefulness at solving stability problems of underground excavations in geological media:

- the possibility of modeling inelastic behaviour of the medium as well as modeling its heterogeneity,

- modeling of discontinuities in the form of preferred directions of weakness (ubiquitous joints model),

- solution of incremental problems, i.e. modeling of individual stages of the tunnel excavation and related changes of stresses that follow, and

- modeling of different types and complex elements of the tunnel support. 


\subsection{Models of the Rock Mass, Support and Lining}

\subsubsection{Geomechanical Properties of the Rock Mass}

Creating an accurate rock mass model is possible only when the data from geological and geotechnical investigations are reliable and relatively accurate. This applies mainly to the geomechanical parameters of the rock and rock mass, its geological structure (especially the orientation of systems of discontinuities) and field of natural stresses.

The data required for the construction of numerical models were obtained in geological and geomechanical investigations, performed within the frames of geological-engineering documentations (Zabuski 1997a, b, c, 1998). In addition, the experience gained and the results obtained in similar analyses, and stability calculations of hydrotechnical tunnels in Świnna Poręba (Zabuski 2002, Zabuski and Thiel 2000) were taken into account. The rock masses in Świnna Poręba and Kąty-Myscowa are both composed of the Carpathian Flysch and characterised by its principal properties. Hard sandstones interbedded by significantly weaker clay or marl shale, sometimes strongly weathered and slaked, prevail in both Świnna Poręba and Kąty-Myscowa. Layering and two systems of joints result in the rock mass being discontinuous and anisotropic.

Due to the relatively shallow depth of the tunnels, it is necessary to take into consideration a gradual improvement of the rock mass quality in a function of increasing depth. In most shallow layers, the influence of negative superficial processes is observable. The rock is thus strongly weathered, eroded and decompressed. Sub-surficial discontinuities cause the mass structure to loosen. The influence of superficial processes diminishes along with the increase in depth, which results in an improved quality of the rock mass. When elaborating the geomechanical models, the parameters of the rock mass were therefore considered to be dependent on the depth rather than being constant.

Necessary functions were formulated, where the elasticity modulus $E$, cohesion $c$ and the angles of internal friction $\phi$ and dilatation $\psi$ were assumed to be depth-dependent (Zabuski 1997a, b, c, 1998). The adopted general relation has a form:

$$
\text { Parameter }=\text { Parameter }_{0} \times\left[A \times H^{1 / 2}+1\right] .
$$

The coefficients denoted as Parameter $_{0}$ and $A$ were calculated on the basis of the values of the rock mass parameters at depths $H=5 \mathrm{~m}$ and $H=30 \mathrm{~m}$, respectively (i.e. at the depth of the test tunnels where in situ tests were carried out and the parameters were determined) (Zabuski 1997a, b, c, 1998). The empirical relationships for individual parameters are:

$$
\begin{aligned}
& E=75000 \times\left[0.2738 \times H^{1 / 2}+1\right], \quad[\mathrm{kPa}] \\
& c=3.92 \times\left[3.66 \times H^{1 / 2}+1\right], \quad[\mathrm{kPa}]
\end{aligned}
$$




$$
\begin{aligned}
& \phi=18.48 \times\left[0.0367 \times H^{1 / 2}+1\right], \\
& \psi=4.62 \times\left[0.0367 \times H^{1 / 2}+1\right] .
\end{aligned}
$$

Other parameters are assumed to be independent of the depth, and their values are as follows:

- Unit volumetric weight $=22 \mathrm{kN} / \mathrm{m}^{3}$,

- Rock tension strength $R_{r}=0$,

- Cohesion of discontinuities $c_{j}=20 \mathrm{kPa}$,

- Friction angle of discontinuities $\phi_{j}=10^{\circ}$,

- Dilatation angle of discontinuities $\psi_{j}=0.25_{j}=2.5^{\circ}$,

- Tension strength of discontinuities $R_{r j}=0$.

The analysis of the rock mass structure shows that the predominant set of joints (direction of weakness) is connected with the shale layers, dipping at about $60^{\circ}$ to the horizontal. It causes tectogenetic anisotropy of the rock mass.

The parameters of the medium in quaternary overburden 5 meters thick are as follows:

- Cohesion $c=17 \mathrm{kPa}$,

- Friction angle $\phi_{n}=5^{\circ}$,

- Elasticity modulus $E_{s n}=750 \mathrm{MPa}$,

- Poisson's coefficient $v_{n}=0.4$,

- Unit volumetric weight $\gamma_{n}=20 \mathrm{kN} / \mathrm{m}^{3}$,

- Dilatation angle $\psi_{n}=0.25 \times n$,

- Tension strength $R_{r n}=0$.

The determination of the characteristics of the field of natural stresses, particularly the ratio of the horizontal to the vertical stresses, is problematic. Because of the lack of empirical data, this ratio was determined based on the formula:

$$
\sigma_{x}=\sigma_{y} \times\left(\frac{v}{1-v}\right)
$$

where $\sigma_{x}$ denotes the lateral horizontal component of stress, $\sigma_{y}$ - the vertical component of stress, and $v$ is Poisson's coefficient. As $v \approx 0.25 \div 0.40$, the ratio $v /(1-v)=$ $0.33 \div 05$. The value of $v=0.4$ was assumed in the geomechanical computational model.

\subsubsection{Model of the Tunnel, Support and Lining}

Calculations were carried out in two main stages. At the first stage, OW, full rock core inside of the tunnel neat line was extracted and supported, while the final permanent lining was modeled at the second stage which is divided into the variants (see Fig. 6). 


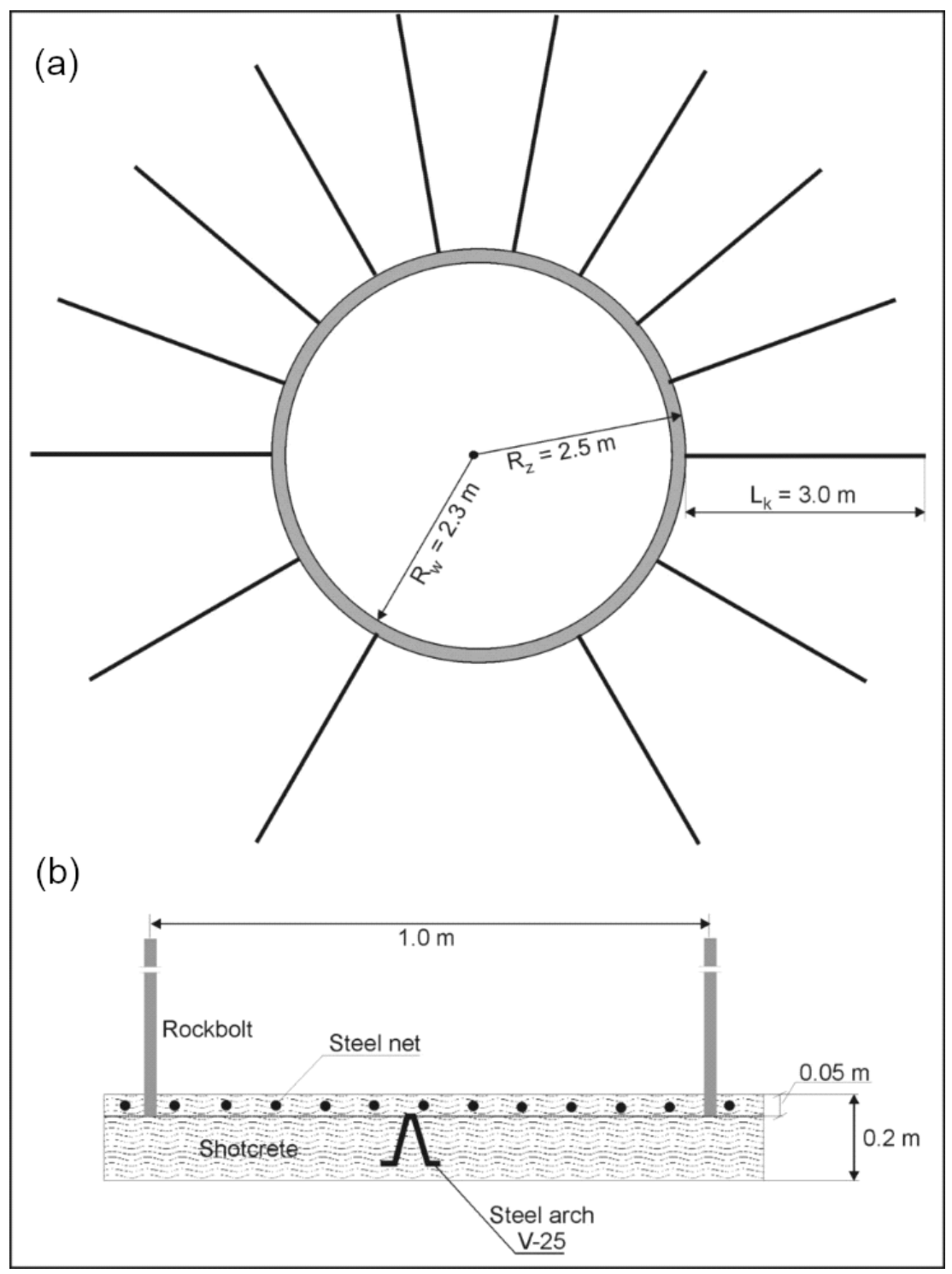

Fig. 7. Support of the tunnel; (a) supported cross-section, (b) support along the longitudinal axis

The support in the model is composed of rockbolts and shotcrete shell reinforced with steel arches. The rockbolts are modelled in the "explicit" mode, as steel rods installed in the holes around the tunnel (Fig. 7).

The parameters of the rockbolt and the contact surface between the rockbolt and rock are as follows:

- Length of the rod, $L_{k}=3.0 \mathrm{~m}$,

- Cross-section area of the rod, $A_{k}=3.8 \times 10^{-4} \mathrm{~m}^{2}$, 
- Tension strength (the force necessary to pull out the rod from the hole), $R_{r k}=118 \mathrm{kN}$,

- Cohesion of the contact between the rod and inject (cementing the rockbolt in a hole) or between the inject and rock, $S_{\text {bond }}=55 \mathrm{kN} / \mathrm{m}$.

- The stiffness of the contact between the rod and inject, $K_{\text {bond }}=10^{7} \mathrm{kN} / \mathrm{m} / \mathrm{m}$.

The shotcrete layer reinforced with steel arches is described by the following set of parameters:

- Cross-section area of 1 running meter, $A_{o w}=0.20 \mathrm{~m}^{2}$,

- Moment of inertia $I_{\text {ow }}=\left(1.0 \times 0.2^{3}\right) / 12=6.667 \times 10^{-4} \mathrm{~m}^{4}$,

- Elasticity modulus $E_{\text {ow }}=3.0 \times 10^{7} \mathrm{kPa}$.

The lining (reinforced concrete) is described by the parameters:

$-A_{o o}=0.4 \mathrm{~m}^{2}$,

$-I_{o o}=\left(1.0 \times 0.4^{3}\right) / 12=0.00533 \mathrm{~m}^{4}$,

- Elasticity modulus $E_{\text {ow }}=3.0 \times 10^{7} \mathrm{kPa}$ (the same as for support).

Both the support and lining are tightly bonded with the surrounding mass.

\subsubsection{Numerical Model}

Figure 8 presents the finite difference mesh for the tunnel at the depth $H=45 \mathrm{~m}$, whereas Figure 9 shows the tunnel with schematically drawn support and lining. The values characterizing the division of the model into finite difference zones, and the elements of support and lining, are given in Table 2.

Table 2. Values characterizing division of the model into finite difference zones, tunnel support and lining

\begin{tabular}{|c|c|c|c|c|c|c|}
\hline $\mathrm{H}$ & \multicolumn{2}{|c|}{ Calculation model } & \multicolumn{2}{c|}{ Tunnel support } & \multicolumn{2}{c|}{ Tunnel lining } \\
\hline$[\mathrm{m}]$ & Elements & Nodes & Elements & Nodes & Elements & Nodes \\
\hline 45 & 12600 & 12831 & 104 & 104 & 96 & 96 \\
\hline
\end{tabular}

There are 14 rockbolts in the cross-section (see Figs. 7 and 9). Each rockbolt is divided into 5 segments and has 6 nodal points. The rockbolts are passive, which means they are pasted in the boreholes with the use of a cement mixture along their whole length.

\section{Results of Calculation}

Stress distribution, displacements, state of failure, etc. in the rock mass as well as the results characterizing the forces and deformations in the support and lining were calculated. Because presenting all the results would be too extensive, only those for the most unfavorable stage WS.2 and for the tunnel depth $H=45 \mathrm{~m}$ are described below. 


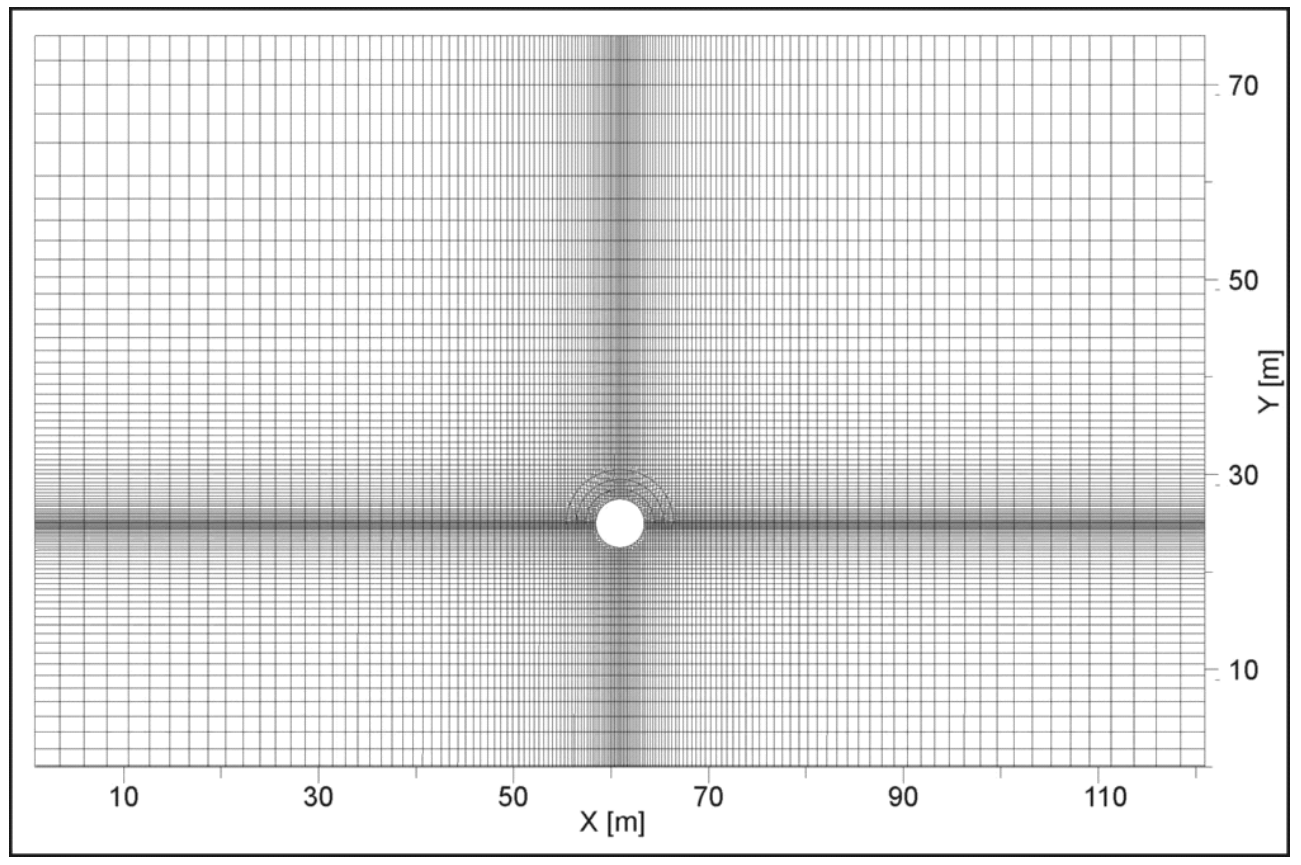

Fig. 8. Finite difference mesh. Tunnel depth $H=45 \mathrm{~m}$

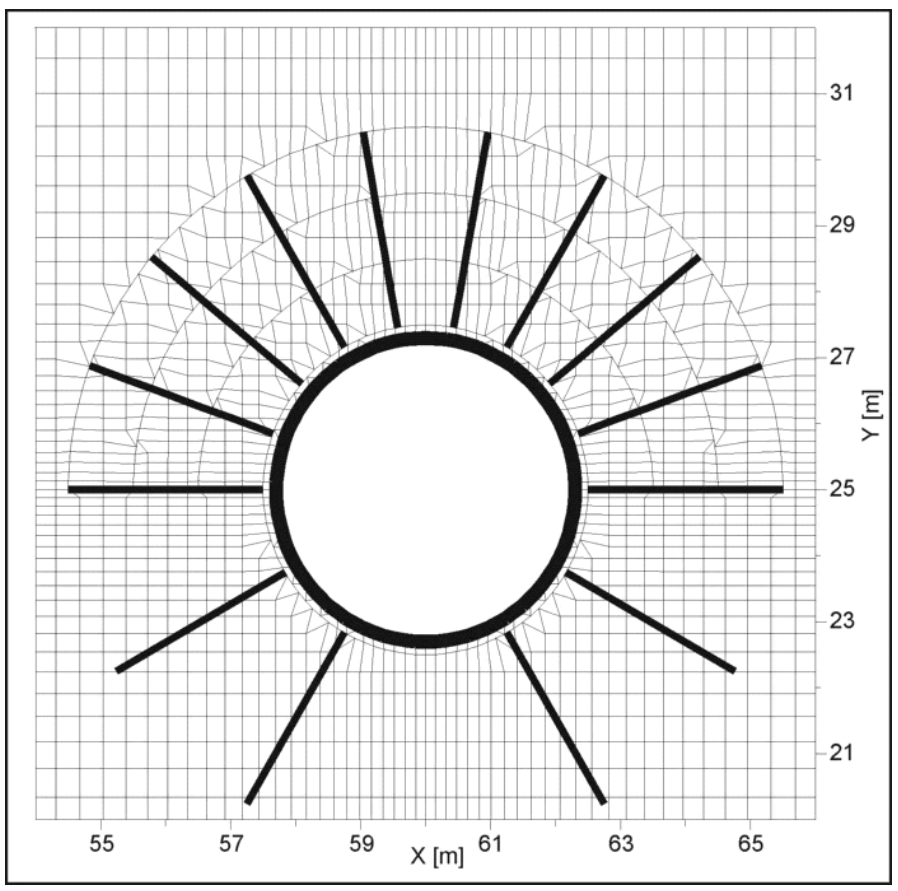

Fig. 9. Finite difference mesh in surroundings of the lined tunnel 


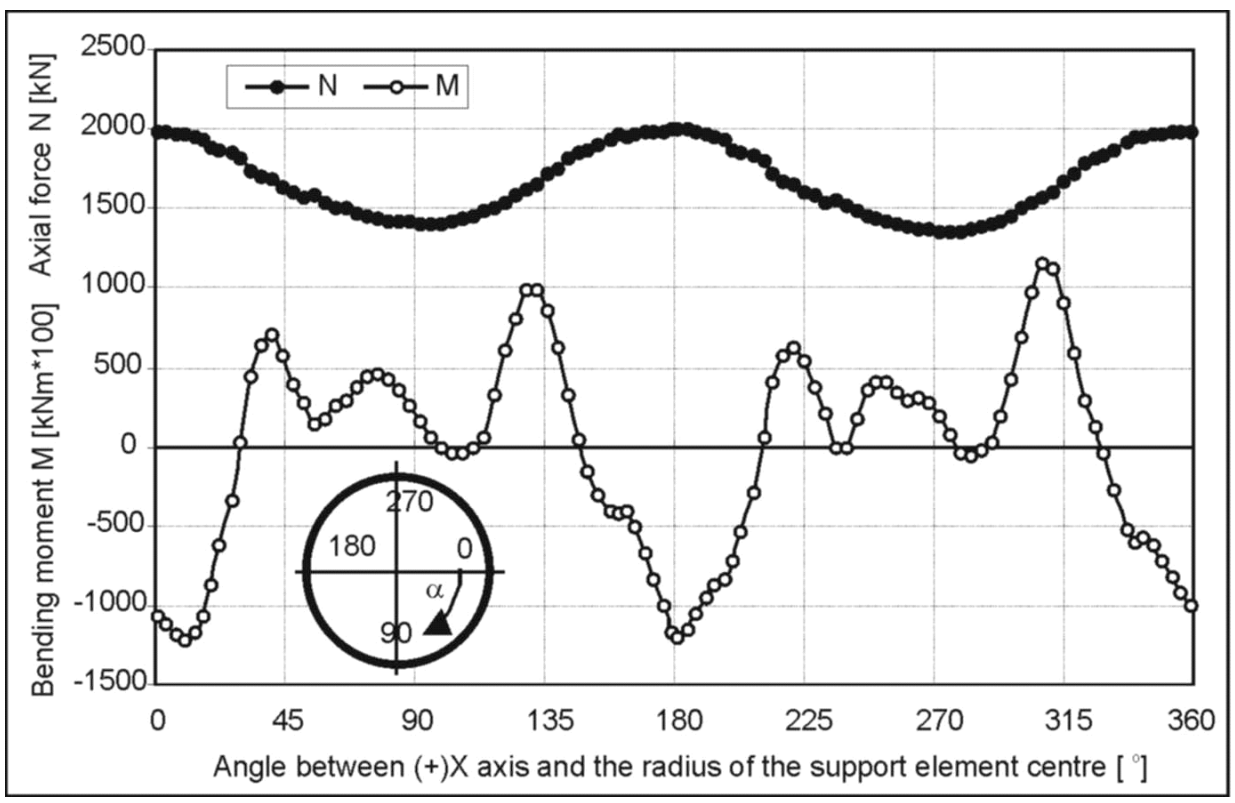

Fig. 10. Internal forces (axial force and bending moment) in preliminary support

The distribution of axial forces and bending moments in the support elements are presented in Figure 10, while the nodal displacements are shown in Figure 11. The circular shape of the tunnel and a relatively low anisotropy of the surrounding rock mass (resulting only from the presence of joint system) make the bending moments relatively low (i.e. their maximum value equals $12 \mathrm{kNm}$ ). In contrast to the moments, axial forces are approximately symmetrical with respect to the vertical axis of the tunnel. The displacement of the tunnel invert is positive, which means that it lifts up. Both the roof and invert move towards the interior of the tunnel (negative convergence means that the distance between the roof and invert decreases), whereas the displacement of lateral walls is almost zero.

The distribution of axial forces and bending moments as well as displacements in the lining are shown in Figures 12, 13 and 14, respectively. It can be seen that:

- the distribution is asymmetrical relative to the vertical central axis of the tunnel; the reason for that is the anisotropy of the rock mass (Pachoud and Schleiss 2016) resulting from the presence of an oblique joint set;

- the largest displacement (settlement) is present in the roof of the tunnel. The invert is uplifted, but its displacement is smaller than that observed in the roof; this means that the tunnel convergence is negative;

- the magnitude of the bending moments is depending only to a small degree on whether the tunnel is filled with water or not. The bending moments are mainly dependent on the depth of the tunnel and the presence or absence of water in the rock mass; and 


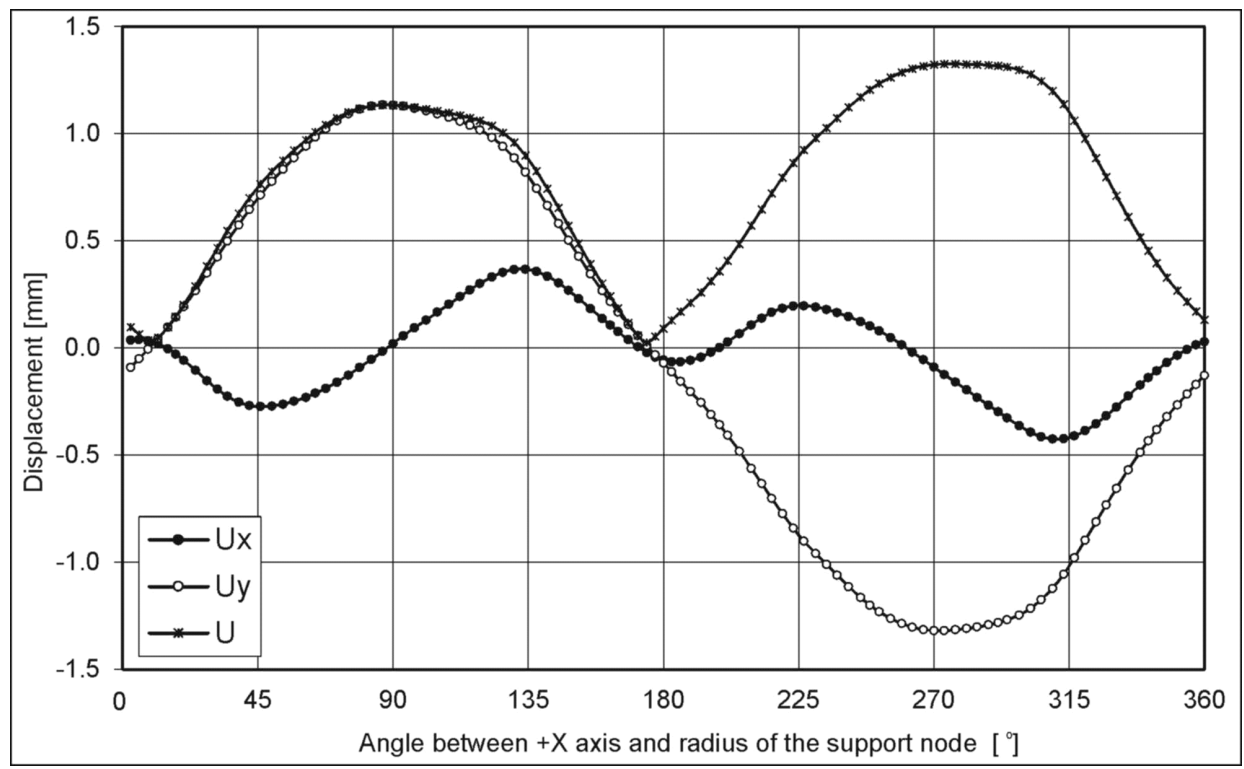

Fig. 11. Displacements of the preliminary support. $U_{x}, U_{y}, U$-displacements in directions $\mathrm{X}, \mathrm{Y}$ and resultant displacements, respectively (+- upwards)

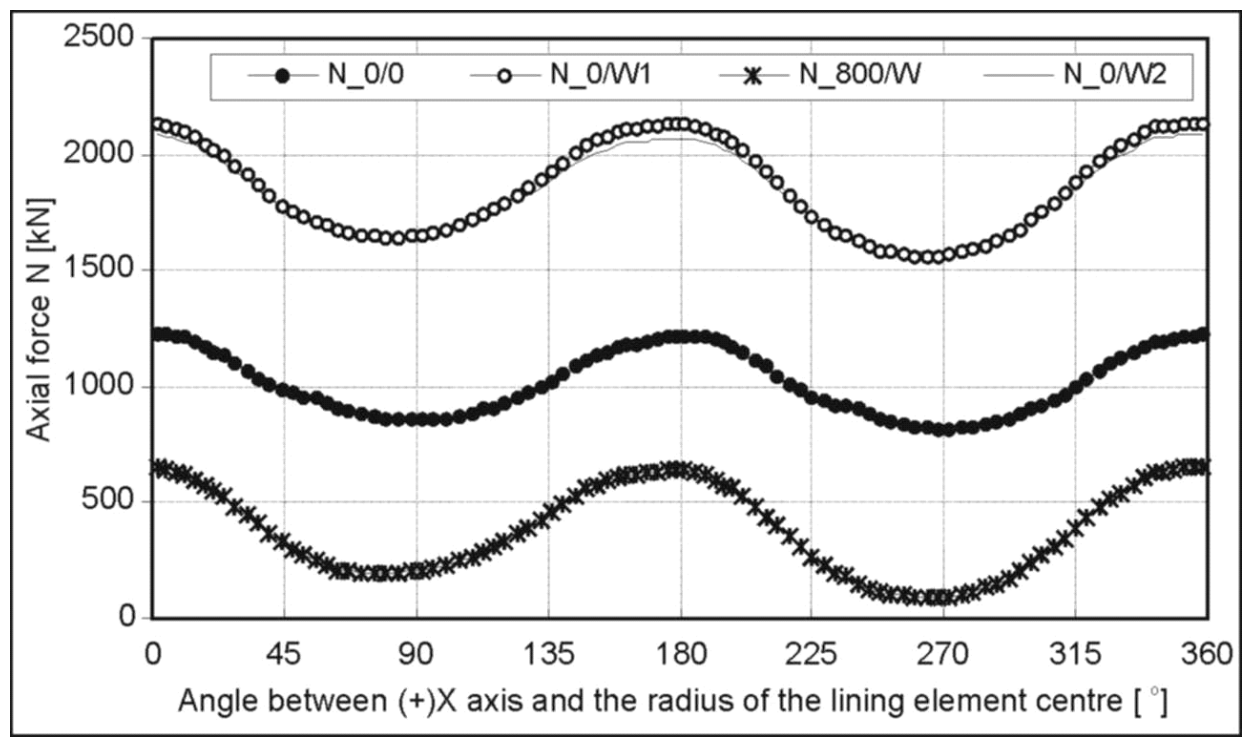

Fig. 12. Axial forces $\mathrm{N}$ in the lining. Variant WS.2

- filling, emptying and re-filling the tunnel with water generate very small, practically negligible changes both in the forces and the displacements.

The distribution of internal forces in the lining and its displacement for the tunnel filled with water versus an empty tunnel are illustrated in Figure 15. The axial force 


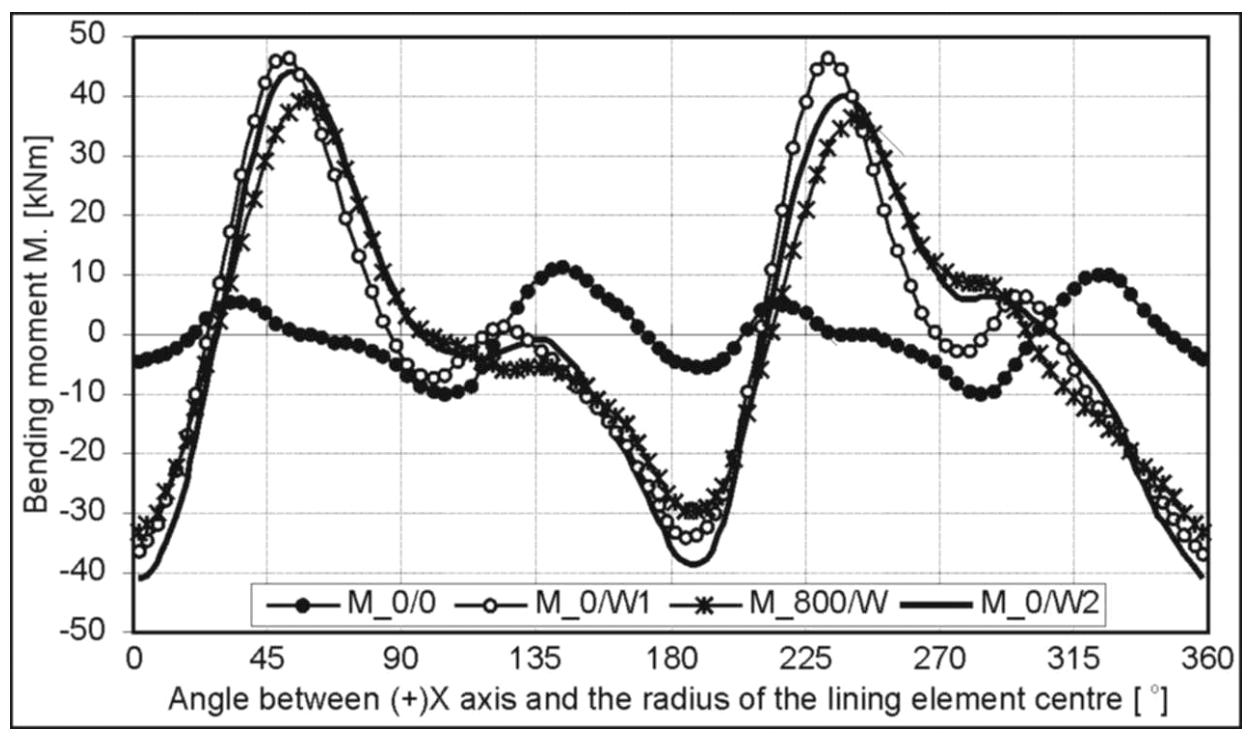

Fig. 13. Bending moments in the lining. Variant WS.2

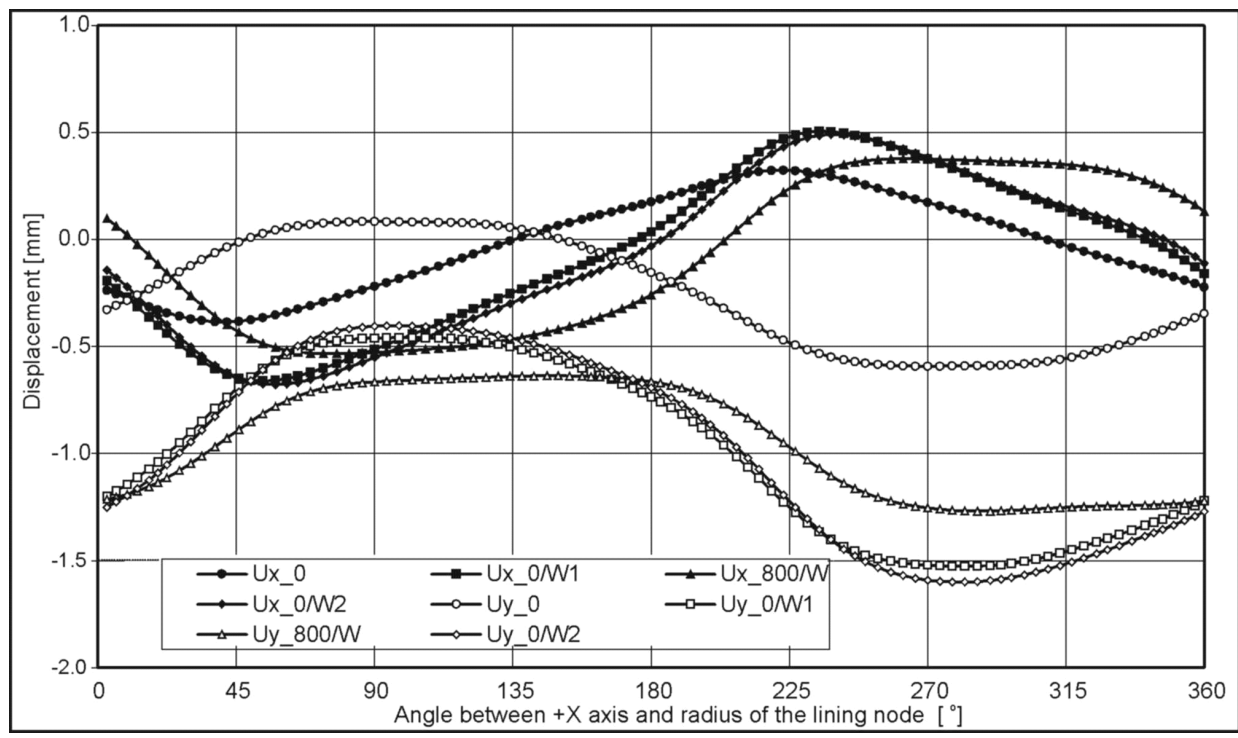

Fig. 14. Displacements of the preliminary support. $U_{x}, U_{y}, U$-displacements in directions $\mathrm{X}, \mathrm{Y}$ and resultant displacements, respectively (+- upwards)

in the lining for the filled state is notably lower than that for the empty tunnel. This significant decrease in the force for the filled tunnel shows a positive effect of external pressure generated in the rock mass. This pressure also has a positive impact on the displacement of the lining, which decreases after filling the tunnel. This effect can be mainly observed when the gap between the rock mass and lining is injected. 


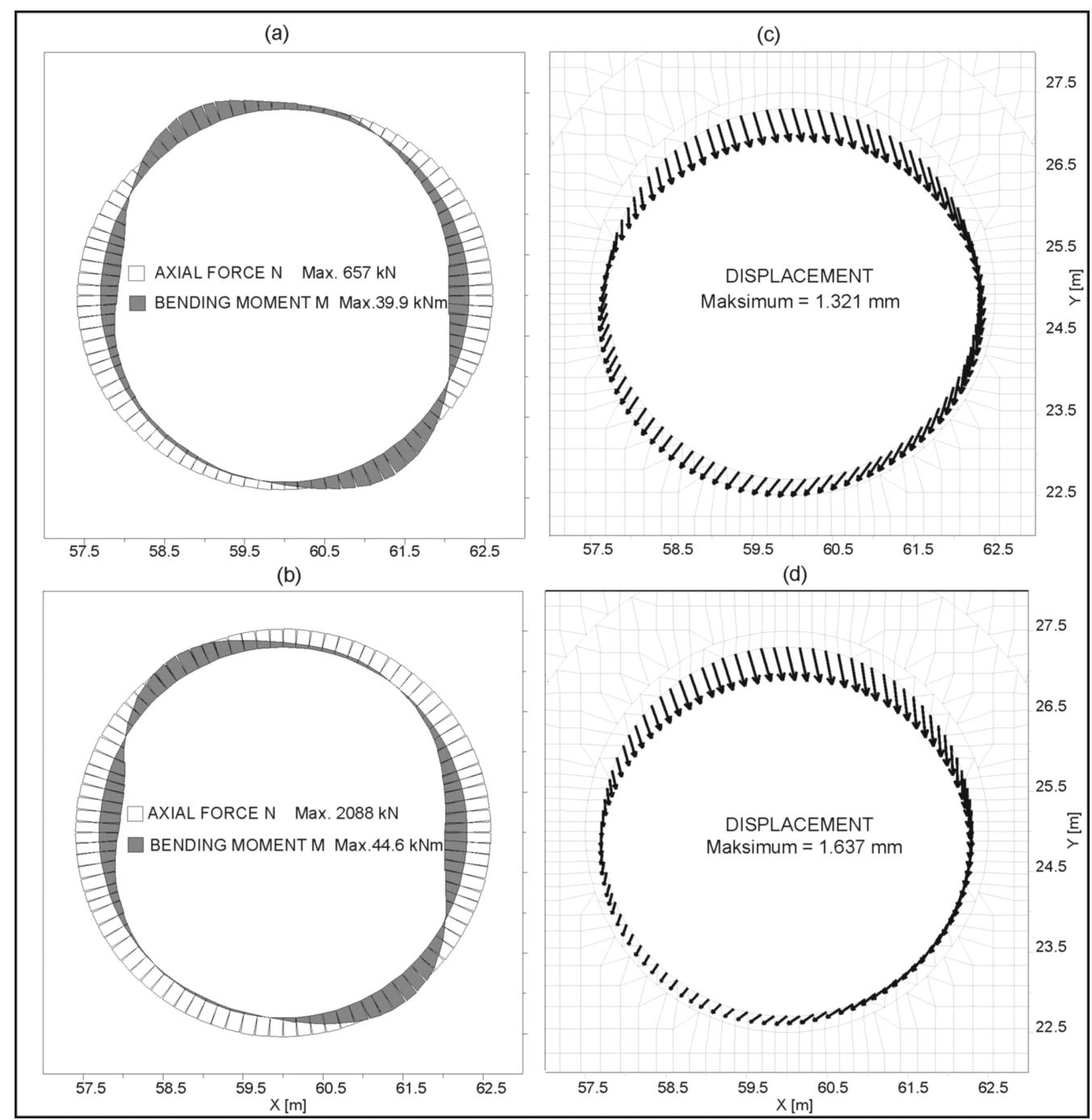

Fig. 15. Internal forces and displacement in the lining, WS.2. Forces: (a) $p_{\text {in }}=800 \mathrm{kPa}$; (b) $p_{\text {in }}=0$ (empty tunnel); Displacement: (c) $p_{\text {in }}=800 \mathrm{kPa}$; (d) $p_{\text {in }}=0$

\section{Final Remarks and Conclusions}

Numerous pressure tunnels have been built in electric power plants outside of Poland, mainly in the Alpine countries (Brekke and Ripley 1993, Seeber 1999, Stering et al 2013, Gerstner 2015). Unlike conventional communication tunnels, these constructions should be considered and designed individually. It is therefore impossible to formulate any standards that could be applied universally.

An array of new solutions for the support and lining of pressure tunnels have been recently developed. New constructional materials have been introduced such as 
foils, geotextiles and prefabricated concrete elements (sometimes with built-in foil, which provides water tightness). Nevertheless, steel shells remain most universally used, mainly because of high internal and, in some cases, high external pressures developing in the tunnels (Bowling 2010, Hachem and Schleiss 2009).

The designs of low-pressure tunnels in Poland should take into account their typical limitations and a limited experience of the local experts with this type of constructions. In the object Kąty-Myscowa discussed in this paper, difficulties are likely to arise already at the excavation and preliminary support stages due to complex geological and hydrogeological conditions present on site. A relatively small cross-section area of the tunnel and its circular shape create favorable circumstances.

While there may be other successful solutions, it seems that the approach described here is appropriate given its cost and the resources available in Poland. Moreover, the solution proposed here is, from the technical point of view, relatively easy to implement. Although the execution of injection could turn out problematic, the recommendations described here can help overcome this potential difficulty, however.

The analysis has been carried out for the tunnel excavation and exploitation, for different variants of the rock mass, internal and external conditions (tunnel depth, excavation sequence, water regime), preliminary support and permanent lining. The displacement and stress distribution in the rock mass and, most of all, forces and displacement in the support and lining were determined. It can be noted that:

- Filling the tunnel with water generates internal pressure $\left(p_{\text {in }}=800 \mathrm{kPa}\right)$ on the walls, causing significant reduction of axial forces in comparison to those acting in the lining of the empty tunnel. The forces in the tunnel at the depth $H=15 \mathrm{~m}$ are negative (tension), whereas at greater depths, the joint work of the rock mass has the ability to withstand internal pressures. The limit depth in the case analyzed equals $H_{\text {lim }}=26.5 \mathrm{~m}$. For $H>H_{\text {lim }}$, the axial forces are compressive. The relationship between the axial force and the depth of the tunnel can be represented by an empirical curve (Figure 16).

- The state of the tunnel (i.e. filled versus empty) has only little impact on the magnitude of bending moments in the lining. Their values depend mainly on the amount of water in the rock mass and increase after filling the tunnel with water; the weakening of the rock mass (between stages WM and WS) has a marginal impact.

- Displacements depends on the depth of the tunnel only to a small degree. The maximum displacement in the most unfavorable variant WS.2 ranges between 1.265 $\mathrm{mm}$ and $-1.637 \mathrm{~mm}$; a vertical displacement prevails.

To conclude, it is worth pointing out that:

- the results of the analysis allow for assessment of the conditions of the tunnel during its excavation and exploitation;

- the analysis was performed based on "conservative" assumptions. This means that in uncertain cases and under uncertain conditions, especially those relating to the rock mass properties, an extreme caution was exercised. 


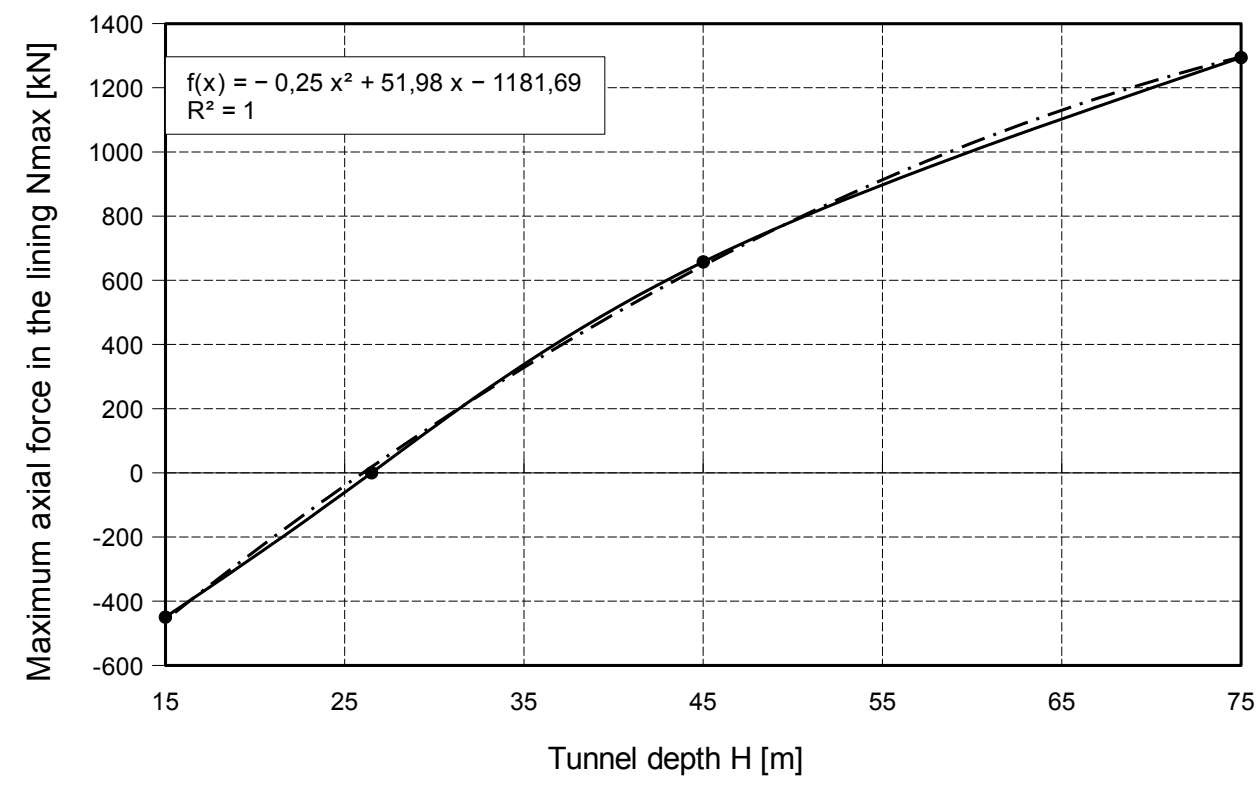

Fig. 16. Maximum axial force Nmax in the lining vs. tunnel depth. Variant WS.2

\section{References}

Barton N., Lien R., Lunde J. (1974) Engineering classification of rock masses for the design of tunnel support, Rock Mechanics, 6, 89-236.

Benson R. P. (1989) Design of unlined and lined pressure tunnels, Tunnelling and Underground Space Technology, 4 (2), 155-170.

Bestyński Z., Thiel K., Zabuski L. (1989) Klasyfikacja geotechniczna masywów fliszowych (Geotechnical classification of flysch rock masses), Rozprawy Hydrotechniczne, 52, 143-163 (in Polish).

Bieniawski Z. T. (1984) Rock Mechanics Design in Mining and Tunneling, Balkema, Rotterdam-Boston.

Bowling A. J. (2010) Performance of steel liner in the power tunnel of the King Rover power development, Tasmania, Austr. J. Civil Eng., 6 (1), 71-80.

Brekke T. L., Ripley B. D. (1993) Design of pressure tunnels and shafts, Analysis and Design Methods. Principles, Practice and Projects, 349-369.

Costa-Pereira A. S., Rodrigues-Carvalho J. A. (1987) Rock mass classifications for tunnel purposes correlations between the systems proposed by Wickham et al, Bieniawski and Rocha, Proc. 6-th Congress ISRM, Montreal, Vol. 2, 841-844.

FLAC 3.40 (1999) User's Manual, Itasca, Minneapolis.

Friedrich R., Zabuski L. (1987) Nowe rozwiązania w budownictwie sztolni ciśnieniowych (New solutions in the construction of the pressure tunnels), Gospodarka Wodna, 5, 117-120 (in Polish).

Gerstner R. (2015), Geological experience with the design of pressure shafts, Geomechanics and Tunneling, 8 (1), 28-34.

Hachem F. E., Schleiss A. J. (2009) The design of steel lined pressure tunnels and shafts, Int. J. Hydropower Dams, 16 (3), 142-151. 
Huang Z., Broch E., Lu M. (2002) Cavern roof stability - mechanism of arching and stabilization by rock bolting, Tunneling and Underground Space Technology, 17 (3), 249-261.

Kumar P. Singh B. (1990) Design of reinforced concrete lining in pressure tunnels considering thermal effects and jointed rock mass, Tunn. Underground Space Technology, 5 (1/2), 91-101.

Müller L. (1978) Der Felsbau, III-r Band: Tunnelbau, Enke Verlag, Stuttgart.

Olsson R., Lindblom U., Glamheden R. (1997) Design of pressure shafts in recognition of rock structure and stress, Proc. Conf. "Tunneling Asia '97”, New Delhi, India, 615-624.

Pachoud A., Schleiss A. J. (2016) Stresses and displacements in steel-lined pressure tunnels and shafts in anisotropic rock under quasi-static internal water pressure, Rock Mech. And Rock Eng., 49 (4), $1263-1287$.

Seeber G. (1975) Neue Entwicklungen für Druckstollen und Druckschächte, Österreichische Ingenieur Zeitschrift, Wien-New York, 5.

Seeber G. (1999) Druckstollen und Druckschächte. Bemessung - Konstruktion - Ausführung, Enke im Georg Thieme Verlag, Stuttgart-New York.

Singh B, Goel R..(1999) Rock mass classification. A practical approach in civil engineering, Elsevier, Amsterdam.(...) - Tokyo.

Stering P., Mayrhuber J., Cerjak H. (2013) Steel pressure shaft linings for hydropower plants - developments in recent VERBUND projects in Austria, Steel Construction, Design and Research, 6 (4), 249-256.

Thiel K., Zabuski L. (1977) Współpraca masywu skalnego z pancerzem stalowym w sztolniach ciśnieniowych (Joint work of the rock mass and steel shell in the pressure tunnels), Rozprawy Hydrotechniczne, 37, 157-181 (in Polish).

Wannenmacher H., Heizmann A., Sabew S. (2015) Operational analysis of pressure tunnel and shaft grouting operations, Proc. Eurock 2016 \& 64th Geomechanics Colloquium Salzburg, Schubert \& Kluckner (ed.).

Wannenmacher H., Krenn H., Bauert M., Komma N., Engel F. (2013) Improved pressure tunnel lining methods, Proc. World Tunnel Cong. Underground - the way to the future, Anagnostou \& Ehrbar (eds.), doi: 10.13140/2/1/3462.9922.

Zabuski L. (1983) Projektowanie i budownictwo sztolni ciśnieniowych w elektrowniach wodnych (Designing and construction of pressure tunnels in electro-power plants), Gospodarka Wodna, 7, 221-226 (in Polish).

Zabuski L. (1984) Investigations and Dimensioning of Pressure Tunnel Linings in Electric Power Plants, Proc. Polish-Yugoslavian Symposium, Gdańsk, 237-242.

Zabuski L. (1997a) Sprawozdanie z realizacji drugiego etapu umowy c2-32/96 (28.04.1997 14.08.1997) (Report from the realization of the second stage c2-32/96 contract), IBW PAN Gdańsk, Internal report (in Polish).

Zabuski L. (1997b) Sprawozdanie z realizacji etapu 3A umowy c2-32/96 (15.08.1997 - 20.11.1997) (Report from the realization of the 3A stage c2-32/96 contract), IBW PAN Gdańsk, Internal report (in Polish).

Zabuski L. (1997c) Analiza wyników badań odksztatcalności i sprężystości masywu skalnego w otworach wiertniczych OM-116 i OM-115 (obiekt "Krempna") (Analysis of the deformability and elasticity of the rock mass in OM-116 i OM-115 boreholes, object "Krempna”), IBW PAN Gdańsk, Internal report (in Polish).

Zabuski L. (1998) Sprawozdanie z realizacji etapu 3B umowy c2-32/96 (20.11.1997-28.02.1998), IBW PAN Gdańsk, Internal report (in Polish).

Zabuski L. (2000) Koncepcja projektowa obudowy wstepnej i obudowy ostatecznej dla sztolni zapory Krempna (The concept of the design of the preliminary support and lining for Krempna dam tunnels), IBW PAN Gdańsk, Internal report (in Polish). 
Zabuski L. (2002) Zachowanie się fliszowego ośrodka skalnego w otoczeniu konstrukcji podziemnej na przykładzie tunelu na niedużej głębokości (Behaviour of the flysch rock mass surrounding underground construction Ố the tunnel on the shallow depth as an example), IBW PAN Gdańsk, 262 p. (in Polish).

Zabuski L. (2019) Three-dimensional analysis of a landslide process on a slope in Carpathian Flysch, Archives of Hydro-Engineering and Environmental Mechanics, 66 (1-2), 27-45.

Zabuski L., Thiel K. (2000) Influence of tunnel depth on its behaviour during construction, Proc. Int. Conf. “Tunneling Asia '2000”, New Delhi, 260-268. 